\title{
Nutritional value, performance, feeding behavior and serum biochemical profile of sheep fed with alfalfa hay replacing Bermuda grass (Cynodon dactylon (L.) Pers.) hay
}

José C. da Silva ${ }^{1 *}$, Antonia C. Véras ${ }^{1}$, Francisco R. de Carvalho ${ }^{1}$, Marcelo A. Ferreira ${ }^{1}$, Evaristo O. de Souza ${ }^{2}$, Ligia G. Barreto ${ }^{1}$, Levi A. Lopes ${ }^{1}$, and Juliana V. da Silva ${ }^{1}$

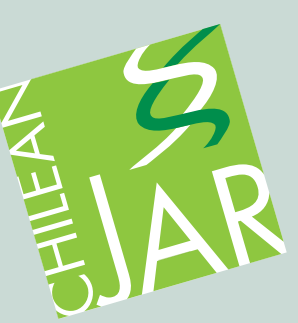

\section{ABSTRACT}

Grasses and legumes are two groups of plants physic and chemically different (amount of crude protein and fiber, mostly), very used in animal feed, whose differences can determine variation in intake, digestibility and animal behavior. We aimed to evaluate performance, feeding behavior and the serum biochemical profile of sheep. The treatments were four levels of substitution of Bermuda grass (Cynodon dactylon [L.] Pers.) hay for alfalfa (Medicago sativa L.) hay (0, 330, 660 and 1000 $\left.\mathrm{g} \mathrm{kg}^{-1} \mathrm{DM}\right)$. The randomized block design was used being two blocks and four treatments with 10 replicates). There were no effects on the performance of animals. On the other hand, there was a positive linear effect ( $P$ $<0.05)$ for intake of DM, organic matter, crude protein (CP), total carbohydrates, and non-fibrous carbohydrates. However, the use of neutral detergent fiber (NDF) showed linear decrease with the increase in alfalfa hay $(\mathrm{P}<$ $0.05)$. CP and NDF decreased linearly $(\mathrm{P}<0.05)$ with the replacement of Bermuda grass hay for alfalfa hay. There were decreasing linear effects $(P<0.05)$ when compared to the time of ingestion and chewing of feed, and increasing linear effects regarding total resting time. Estimated passage rate, density of particles and blood glucose showed a positive linear effect $(\mathrm{P}<0.05)$, while weight of gastrointestinal contents decreased according to alfalfa levels $(\mathrm{P}<0.05)$. The replacement of Bermuda grass hay by alfalfa hay to promote improvement in the performance is not recommended.

Key words: Behavior, digestibility, intake, legumes, Medicago sativa.

'Universidade Federal Rural de Pernambuco, Zootecnia, Rua Dom Manoel de Medeiros s/n, Recife, Pernambuco, Brasil.

"Corresponding author (ricardocoelho26@yahoo.com.br).

${ }^{2}$ Universidade Federal Rural de Pernambuco, Unidade Acadêmica de Serra Talhada, Avenida Gregório Ferraz Nogueira s/n, Serra Talhada, Pernambuco, Brasil.

Received: 8 April 2017.

Accepted: 30 July 2017.

doi:10.4067/S0718-58392017000400340

\section{INTRODUCTION}

The majority of ruminant production systems in Brazil uses grass-based feed. However, grasses, mainly tropical grasses, even though they have higher growth rates, generally have a restricted nutritional value especially regarding the amount and availability of protein. On the other hand, legumes such as alfalfa (Medicago sativa $\mathrm{L}$.) represent an excellent alternative for the production of ruminant animals since they have a greater nutritional value, are diffused worldwide and have a satisfactory cost-benefit relation.

Grasses and legumes are two groups with different characteristics widely used in animal feed worldwide. Two representatives of grasses and legumes used as hay are, respectively, Bermuda grass (Cynodon dactylon [L.] Pers.) and alfalfa. Some of the existing physical differences between these feeds are higher density of particles, higher rate of digestion and lower particle size for legumes (Kammes and Allen, 2012). Their chemical properties are higher crude protein and lower effective fiber, which promotes a reduction in the use of concentrated protein for ruminant feed, consequently reducing production costs.

Increased digestion and passage rates, common characteristics in legumes, determine a lower rumen filling with a direct impact on the increase in consumption due to the less space occupied by the fiber fraction (Agudelo, 2007). Digestion rates of structural carbohydrates are often faster for feed based on legume than grasses. The higher rate of passage may, however, decrease the digestibility of some nutrients (Vieira et al., 2008; Cannon et al., 2010) and therefore affect performance. Differences between feeds, especially a physical dissimilarity regarding fibrous contents, determine alterations in feeding behavior, with a lower total intake time and an animal resting for longer as the amount of fiber decreases.

We aimed to evaluate the replacement of Bermuda grass hay for alfalfa hay about performance, feeding behavior and the serum biochemical profile of sheep.

\section{MATERIALS AND METHODS}

The experiment was conducted at the Animal Science Department of the Federal Rural University of Pernambuco (UFRPE) located in the Brazilian Northeast region. The area is characterized by a hot and humid climate, with an average temperature recorded during the experimental period of $29^{\circ} \mathrm{C}, 79 \% \mathrm{RH}$ and rainfall of $940 \mathrm{~mm}$. Forty male sheep without a defined breed were used. They were not castrated, initially weighed $26.5 \pm 1.85 \mathrm{~kg}$ 
(at the beginning of the confinement) and had 8-mo age. They were confined for approximately $100 \mathrm{~d}$ in individual pens $(1 \times 2 \mathrm{~m})$ provided with feeder and drinker. Before the beginning of the experiment, the animals were wormed against endoparasites and ectoparasites. They also received an ADE-based vitamin complex.

This research was approved by the Ethics Committee of the Federal Rural University of Pernambuco for animal experimentation and registered under the nr CEUA/UFRPE $119 / 2015$.

Before the confinement, in order to avoid compensatory growth and adaptation to the facilities and feed handling, the animals were fed for $44 \mathrm{~d}$ with Bermuda grass hay (Cynodon dactylon [L.] Pers.), alfalfa hay (Medicago sativa L.), bran and soybean-based concentrated corn (Zea mays L., Glycine $\max$ [L.] Merr.) at a 50:50 ratio. After the adjustment period, the animals were confined for $56 \mathrm{~d}$ and subjected to treatments.

The treatments were four levels of substitution of Bermuda grass hay for alfalfa hay: 0, 330, 660 and 1000 $\mathrm{g} \mathrm{kg}^{-1}$ based on DM. The experimental diets were composed of alfalfa hay, Bermuda grass hay, corn meal, soybean meal, mineral mix and calcitic limestone (Table 1). The diets (isoproteic) were formulated according to NRC (2007) to allow a weight gain of approximately $200 \mathrm{~g} \mathrm{~d}^{-1}$. The feeding (ad libitum) occurred twice daily (at 08:00 and 15:00 h) with a complete feed adjusted every $3 \mathrm{~d}$. When required, the intake was adjusted allowing $10 \%$ remains.

Table 1. Nutritional composition of feeds, proportion of ingredients and nutritional composition of experimental diets.

\begin{tabular}{|c|c|c|c|c|}
\hline Nutrients ( $\left.\mathrm{g} \mathrm{kg}^{-1} \mathrm{DM}\right)$ & $\begin{array}{c}\text { Alfalfa } \\
\text { hay }\end{array}$ & $\begin{array}{l}\text { Bermuda } \\
\text { grass hay }\end{array}$ & $\begin{array}{l}\text { Corn } \\
\text { grains }\end{array}$ & $\begin{array}{c}\text { Soybean } \\
\text { meal }\end{array}$ \\
\hline Dry matter, $\mathrm{g} \mathrm{kg}^{-1} \mathrm{FM}$ & 821 & 837 & 888 & 888 \\
\hline Organic matter & 859 & 901 & 980 & 920 \\
\hline Mineral matter & 141 & 99 & 20 & 80 \\
\hline Crude protein & 181 & 97 & 77 & 438 \\
\hline Ether extract & 15 & 19 & 45 & 18 \\
\hline Neutral detergent fiber & 355 & 703 & 108 & 190 \\
\hline Non-fiber carbohydrates & 330 & 101 & 751 & 275 \\
\hline \multirow[t]{2}{*}{ Total carbohydrates } & 685 & 804 & 858 & 465 \\
\hline & \multicolumn{4}{|c|}{ Replacement levels ( $\left.\mathrm{g} \mathrm{kg}^{-1} \mathrm{DM}\right)$} \\
\hline Ingredients, $\mathrm{g} \mathrm{kg}^{-1} \mathrm{DM}$ & 0 & 330 & 660 & 1000 \\
\hline Bermuda grass hay & 600 & 400 & 200 & 0 \\
\hline Alfalfa hay & 0 & 200 & 400 & 600 \\
\hline Corn grains & 220 & 252 & 291 & 328 \\
\hline Soybean meal & 165 & 133 & 95 & 58 \\
\hline Mineral mix & 6 & 8 & 10 & 12 \\
\hline Calcitic limestone & 4 & 2 & 0 & 0 \\
\hline Dicalcium phosphate & 5 & 5 & 4 & 2 \\
\hline Ingredients ( $\left.\mathrm{g} \mathrm{kg}^{-1} \mathrm{DM}\right)$ & \multicolumn{4}{|c|}{ Nutritional composition } \\
\hline Dry matter, $\mathrm{g} \mathrm{kg}^{-1} \mathrm{FM}$ & 858 & 855 & 851 & 847 \\
\hline Organic matter & 920 & 917 & 915 & 905 \\
\hline Mineral matter & 80 & 83 & 85 & 88 \\
\hline Crude protein & 143 & 149 & 152 & 157 \\
\hline Ether extract & 23 & 23 & 24 & 24 \\
\hline Neutral detergent fiber & 478 & 405 & 332 & 260 \\
\hline Non-fiber carbohydrates & 271 & 332 & 397 & 460 \\
\hline Total carbohydrates & 748 & 736 & 729 & 719 \\
\hline Total digestible nutrients & 603 & 604 & 581 & 584 \\
\hline
\end{tabular}

FM: Fresh matter.
The DM intake was determined by the difference between the amount of feed offered and leftovers. Every $3 \mathrm{~d}$, feed samples (Bermuda hay, alfalfa hay, corn meal, soybean meal, mineral mix and calcitic limestone) and leftovers were collected. They were identified and pre-dried in a forced-air ventilation oven at $55 \pm 5^{\circ} \mathrm{C}$ for $72 \mathrm{~h}$. Then, they were withdrawn and processed in a Willey mill with a $2 \mathrm{~mm}$ sieve to determine the production of fecal DM (PFDM) and a portion ground at $1 \mathrm{~mm}$ to perform the analysis of DM content (method 967.03), mineral matter (MM) (method 942.05), organic matter (OM), crude protein (CP) (method 988.05), ether extract (EE) (method 920.29) and neutral detergent fiber (NDF) (method 985.29) following the recommendations of the Association of Official Analytical Chemists (AOAC, 1990). To estimate total carbohydrates and total digestible nutrients (TDN), the equations proposed by Sniffen et al. (1992) and Weiss (1999) were used.

The digestibility of nutrients (DN) was obtained from the amount of nutrients retained in relation to the total nutrient intake. To estimate the PFDM, a fiber in indigestible acid detergent (IAD) was used as an internal indicator. Samples were collected from the feed provided, remains and feces (taken directly from the rectum) for five consecutive days. Feces were collected at different times (06:00, 09:00, 12:00, 15:00 and 18:00 h). The samples were weighed, identified and then frozen at $-20^{\circ} \mathrm{C}$ to ultimately form one composite sample per animal. Samples already identified were pre-dried in a forced-air ventilation oven at $55 \pm 5^{\circ} \mathrm{C}$ for $72 \mathrm{~h}$. At the end of this period, they were withdrawn and processed in a grinder with a $2 \mathrm{~mm}$ sieve. Samples of feed leftovers and feces were weighed (in duplicate) and wrapped in previously identified non-woven fabric bags (TNT, $100 \mu$ ), with $5 \times 5$ dimensions, keeping the proportion of $20 \mathrm{mg} \mathrm{DM} \mathrm{cm}^{-2}$, then dried and weighed as proposed by Casali et al. (2008). Then, the samples were incubated in the rumen of a fistulated buffalo during $288 \mathrm{~h}$. After this period, the bags were removed and washed with water until its total whitening. Then, they were placed in a forced-air ventilation oven at 55 $\pm 5^{\circ} \mathrm{C}$ for $48 \mathrm{~h}$. The washing with an acid washing solution was subsequently performed. Its residue was considered an IAD (Casali et al., 2008).

The water intake was obtained by the difference between the final and initial weights of buckets after their value had been corrected by subtracting the average loss of water by evaporation measured from four buckets arranged in the experimental shed.

The weight gain of the animals was measured by the difference between initial and final body weight. Before each weighing, the animals were subjected to a solid fast for $16 \mathrm{~h}$. Feed conversion (FC) was calculated by dividing the DM intake (DMI, $\mathrm{kg} \mathrm{d}^{-1}$ ) by the average daily gain (ADG, $\mathrm{kg} \mathrm{d}^{-1}$ ).

The record of behavioral parameters was made for $24 \mathrm{~h}$ by using the spot scanning instant method Martin and Bateson (1988) at intervals of $5 \mathrm{~min}$. The shed was kept lit by artificial lighting at night throughout the experiment. During observation intervals, the following behavioral variables 
were determined: feed intake time, chewing time (sum of the intake and rumination time) and resting time.

The record of the weight of the gastrointestinal tract contents (GTC) was obtained by calculating the difference between the weight of filled organs and emptied organs after the slaughter of the animals at the end of the experiment. Pre-slaughter procedures were in accordance with good animal welfare practices.

The estimated passage rate $\left(\mathrm{K}_{\mathrm{p}}\right)$ was calculated according to NRC (2001) using the following equation: $K_{p}=3.362+$ $0.479 X_{1}-0.007 X_{2}-0.017 X_{3}$, where $X_{1}$ is DMI (\% of body weight), $X_{2}$ is percentage of the concentrate in the feed, and $X_{3}$ is percentage of NDF in the feed.

Blood serum biochemical analyses were performed using samples collected $4 \mathrm{~h}$ after the supply of feed in tubes without anticoagulants, which remained at rest until complete coagulation. Tubes were then centrifuged at 4000 $\mathrm{rpm}$ for $10 \mathrm{~min}$. The obtained serum was transferred to labeled microtubes and then stored in a freezer at $-20{ }^{\circ} \mathrm{C}$ until the time of analyses. The concentrations of metabolites glucose, triglyceride, cholesterol, urea, albumin, creatinine and total proteins were determined using a semi-automatic biochemical analyzer D-250 and commercial kits (Doles, Goiânia, Goiás, Brasil).

The experimental design was randomized complete block, being two blocks and four treatments with 10 replicates. The statistical model was $Y_{i j}=\mu+T_{i}+b_{j}+\varepsilon_{i j}$, where $Y_{i j}$ is the response variable, $\mu$ is the effect of the general average, $T_{i}$ is the effect of the treatment, $b_{j}$ is the effect of the block, and $\varepsilon_{i j}$ is the random error. Data were interpreted by PROC GLM for ANOVA and PROC REG for regression analysis using the Statistical Analysis Systems software version 9.1
(SAS Institute, Cary, North Carolina, USA). Data normality (Shapiro-Wilk at $5 \%$ probability) was verified by the UNIVARIATE procedure (PROC UNIVARIATE) of SAS. The mean standard error was obtained from the original data. Differences between treatments were considered significant when $\mathrm{P}<0.05$.

\section{RESULTS}

There was nonsignificant effect $(\mathrm{P}>0.05)$ of replacing Bermuda grass hay for alfalfa hay regarding body weight (initial and final), weight gain (total and daily) and feed conversion (Table 2). On the other hand, there was a positive linear effect $(\mathrm{P}<0.05)$ for $\mathrm{DM}$ intake, organic matter, protein, total carbohydrates, non-fibrous carbohydrates, and a negative linear effect on DM intake, expressed in relation to body weight and neutral detergent fiber (Table 2).

The replacement of Bermuda grass hay for alfalfa hay had a negative linear effect $(\mathrm{P}<0.05)$ on the digestibility of $\mathrm{CP}$ and NDF (Table 2). However, it did not change $(\mathrm{P}>0.05)$ the digestibility of DM, organic matter, total carbohydrates, non-fibrous carbohydrates and total digestible nutrient contents (Table 2). Water intake suffered nonsignificant effects $(P>0.05)$ by replacing Bermuda grass hay for alfalfa hay (Table 3 ).

There were decreasing linear effects $(\mathrm{P}<0.05)$ in relation to the total time of ingestion and chewing of feed and increasing linear effects regarding total resting time. However, it did not change $(\mathrm{P}>0.05)$ rumination time (Table $3)$. The estimated passage rate and the density of particles and blood glucose showed a positive linear effect $(\mathrm{P}<0.05)$,

Table 2. Performance, intake and digestibility of nutrients in sheep fed alfalfa hay on replacement Bermuda grass hay.

\begin{tabular}{|c|c|c|c|c|c|c|c|}
\hline \multirow[b]{2}{*}{ Items } & \multicolumn{4}{|c|}{ Replacement levels (g kg-1 DM) } & \multirow[b]{2}{*}{$\hat{\mathrm{Y}}$} & \multirow[b]{2}{*}{ P value } & \multirow[b]{2}{*}{ SEM } \\
\hline & 0 & 330 & 660 & 1000 & & & \\
\hline \multicolumn{8}{|c|}{ Performance } \\
\hline Initial body weight, $\mathrm{kg}$ & 26.33 & 26.76 & 26.24 & 26.52 & 26.46 & 0.7766 & 0.2919 \\
\hline Final body weight, kg & 39.10 & 39.61 & 39.61 & 40.08 & 39.60 & 0.8573 & 0.4458 \\
\hline Total weight gain, $\mathrm{kg}$ & 12.77 & 12.85 & 13.37 & 13.56 & 13.14 & 0.8453 & 0.3561 \\
\hline Average daily gain, $\mathrm{g} \mathrm{d}^{-1}$ & 228.00 & 229.00 & 239.00 & 242.00 & 234.50 & 0.8438 & 0.4458 \\
\hline Feed conversion & 6.082 & 6.238 & 6.628 & 6.632 & 6.3950 & 0.6403 & 0.1802 \\
\hline \multicolumn{8}{|c|}{ Nutrient intake } \\
\hline Dry matter, $\mathrm{g} \mathrm{d}^{-1}$ & 1361 & 1408 & 1534 & 1554 & $\hat{\mathrm{Y}}=1359.905+3.510 \mathrm{X}$ & 0.0071 & 0.3561 \\
\hline$\%$ Body weight & 2.88 & 2.82 & 2.59 & 2.60 & $\hat{\mathrm{Y}}=2.990-0.106 \mathrm{X}$ & 0.0180 & 0.0423 \\
\hline Organic matter, $\mathrm{g} \mathrm{d}^{-1}$ & 1252 & 1290 & 1403 & 1418 & $\hat{\mathrm{Y}}=1261.410+2.895 \mathrm{X}$ & 0.0163 & 2.8354 \\
\hline Crude protein, $\mathrm{g} \mathrm{d}^{-1}$ & 205 & 215 & 230 & 236 & $\hat{\mathrm{Y}}=203.430+0.574 \mathrm{X}$ & 0.0049 & 1.5117 \\
\hline Total carbohydrates, $\mathrm{g} \mathrm{d}^{-1}$ & 1004 & 1041 & 1134 & 1149 & $\hat{Y}=1001.280+2.199 X$ & 0.0200 & 3.8149 \\
\hline $\mathrm{NDF}, \mathrm{g} \mathrm{d}^{-1}$ & 610 & 530 & 496 & 399 & $\hat{\mathrm{Y}}=608.830-3.348 \mathrm{X}$ & 0.0001 & 14.033 \\
\hline $\mathrm{NFC}, \mathrm{g} \mathrm{d}^{-1}$ & 397 & 497 & 621 & 724 & $\hat{\mathrm{Y}}=396.900+5.575 \mathrm{X}$ & 0.0001 & 0.6460 \\
\hline \multicolumn{8}{|c|}{ Digestibility $\left(\mathrm{g} \mathrm{kg}^{-1}\right)$} \\
\hline Dry matter & 621.2 & 628.5 & 607.2 & 615.7 & 618.1 & 0.4701 & 0.5152 \\
\hline Organic matter & 637.5 & 641.6 & 618.5 & 625.1 & 630.8 & 0.3308 & 0.5223 \\
\hline Crude protein & 708.9 & 693.4 & 681.6 & 660.8 & $\hat{\mathrm{Y}}=709.594-0.0780 \mathrm{X}$ & 0.0426 & 0.6591 \\
\hline Total carbohydrates & 622.6 & 630.9 & 605.8 & 619.8 & 619.7 & 0.4417 & 0.5723 \\
\hline NDF & 443.7 & 421.6 & 282.5 & 202.9 & $\hat{Y}=466.854-0.4306 X$ & 0.0001 & 2.0338 \\
\hline NFC & 872.4 & 836.6 & 842.2 & 841.2 & 848.1 & 0.4719 & 0.7280 \\
\hline TDN & 602.5 & 604.1 & 581.2 & 584.3 & 593.0 & 0.5128 & 0.4775 \\
\hline
\end{tabular}

SEM: Standard error of the mean; NDF: neutral detergent fiber; NFC: non-fiber carbohydrates; TDN: total digestible nutrient. 
Table 3. Sheep feeding behavior and physical traits of digest fed alfalfa hay replacing Bermuda hay.

\begin{tabular}{|c|c|c|c|c|c|c|c|}
\hline \multirow[b]{2}{*}{ Items } & \multicolumn{4}{|c|}{ Replacement levels ( $\left.\mathrm{g} \mathrm{kg}^{-1} \mathrm{DM}\right)$} & \multirow[b]{2}{*}{$\hat{\mathrm{Y}}$} & \multirow[b]{2}{*}{$\mathrm{P}$ value } & \multirow[b]{2}{*}{ SEM } \\
\hline & 0 & 330 & 660 & 1000 & & & \\
\hline \multicolumn{8}{|c|}{ Feeding behavior } \\
\hline Total feeding time, $\min$ & 337 & 271 & 270 & 270 & $\hat{Y}=333.25-3.475 X$ & 0.0007 & 7.6262 \\
\hline Total rumination time, $\min$ & 555 & 546 & 528 & 518 & 537 & 0.4730 & 9.2442 \\
\hline Total chewing time, min & 892 & 816 & 798 & 788 & $\hat{Y}=872.60-1.645 X$ & 0.0080 & 12.9515 \\
\hline Total resting time, min & 558 & 615 & 643 & 653 & $\hat{Y}=569.75+1.575 X$ & 0.0231 & 12.8861 \\
\hline \multicolumn{8}{|c|}{ Physical traits } \\
\hline Density, $\mathrm{g} \mathrm{mL}^{-1}$ & 0.197 & 0.193 & 0.248 & 0.324 & $\hat{Y}=0.132+0.043 X$ & 0.0001 & 0.0099 \\
\hline Passage rate, $\%$ & 3.95 & 4.10 & 4.38 & 4.51 & $\hat{\mathrm{Y}}=3.9379+0.010 \mathrm{X}$ & 0.0001 & 0.0801 \\
\hline Gastrointestinal tract content, $\mathrm{kg}$ & 6.661 & 6.161 & 5.509 & 5.154 & $\hat{\mathrm{Y}}=6.6770-0.026 \mathrm{X}$ & 0.0200 & 0.0097 \\
\hline Water intake, $\mathrm{L}$ & 5.985 & 6.359 & 6.271 & 6.149 & 6.191 & 0.8784 & 0.1790 \\
\hline
\end{tabular}

SEM: Standard error of the mean.

while the weight of gastrointestinal contents decreased according to alfalfa levels $(\mathrm{P}<0.05)$ (Table 3$)$.

The replacement of Bermuda grass hay for alfalfa hay linearly increased $(\mathrm{P}<0.05)$ glucose levels (Table 4$)$. However, it did not change significantly $(\mathrm{P}<0.05)$ the levels of cholesterol, triglyceride, creatinine, albumin and total protein.

\section{DISCUSSION}

Although there has been a decrease in the digestibility of $\mathrm{CP}$ and NDF with the increase in alfalfa levels, this legume provided a supply of nutrients sufficient to promote weight gain equal to animals fed only with grass (Table 2). This demonstrates a quality, not only of proteins, in providing tissue growth, but also a higher digestion ability of their carbohydrates, also indicating the capacity of reducing the amount of concentrated proteins (soybean meal) and mineral sources in feed with the substitution (Table 1). The legume forages have high $\mathrm{CP}$ and minerals especially $\mathrm{Ca}$ and P (Gusha et al., 2014). Gusha et al. (2013) reported that legumes have demonstrated in in vitro and in vivo digestibility studies that they can be used as protein supplements.

The nutrient input provided by the increase in alfalfa was favored by the increase in the consumption of DM and nutrients (Table 2), which increased (though without feed conversion having been increased) due to the marked contribution of the physical characteristics of legumes, i.e., the higher rate of digestion and passage of legumes.
Lima Jr. et al. (2014) and Maciel et al. (2015) reported that legumes could favor the intake compared with grass.

The increase in the passage rate $\left(\mathrm{K}_{\mathrm{p}}\right.$, Table 3$)$ may have been the main factor contributing to the decrease in digestibility because, according to Riaz et al. (2014), the increase in the passage of the digesta may decrease the digestibility of some nutrients and therefore affect performance. Clauss et al. (2011) reported that increasing $\mathrm{K}_{\mathrm{p}}$, decreases the retention particles in the rumen. A greater rumen volume enables a longer retention time and thus greater feed degradation, which may partly compensate for the increase in $\mathrm{K}_{\mathrm{p}}$ (Berends et al., 2015). Additionally, legumes have, in general, faster rates of digestion of structural carbohydrates compared to grasses (Agudelo, 2007; Bureenok et al., 2016). In this context, particle size and density are factors that directly affect the $\mathrm{K}_{\mathrm{p}}$. Therefore, the higher density recorded (Table 3 ) may have contributed to an increase in the passage of the digesta of animals fed with alfalfa hay.

These aforementioned physical characteristics, if on the one hand contributed to the decreased digestibility, on the other hand effectively influenced the increase in the consumption of nutrients. Missio et al. (2009) and Manni et al. (2013) reported that reducing the level of fiber in the diets and increasing the $\mathrm{K}_{\mathrm{p}}$, thereby decreasing retention in the rumen, resulting in a linear increase in intake. This can be explained initially by the linear decrease in the consumption of NDF (Table 2), which had its proportion in the diet decreased with increasing levels of alfalfa hay (Table 1). Furthermore, the high density, which is higher in

Table 4. Blood biochemistry parameters in sheep fed alfalfa hay replacing Bermuda hay.

\begin{tabular}{|c|c|c|c|c|c|c|c|}
\hline \multirow[b]{2}{*}{ Items } & \multicolumn{4}{|c|}{ Replacement levels $\left(\mathrm{g} \mathrm{kg}^{-1} \mathrm{DM}\right)$} & \multirow[b]{2}{*}{$\hat{Y}$} & \multirow[b]{2}{*}{$P$ value } & \multirow[b]{2}{*}{ SEM } \\
\hline & 0 & 330 & 660 & 1000 & & & \\
\hline Glucose, $\mathrm{mg} \mathrm{dL}^{-1}$ & 92.51 & 95.00 & 97.24 & 115.06 & $\hat{Y}=82.166+7.146 X$ & 0.0072 & 2.7609 \\
\hline Cholesterol, mg dL $\mathrm{m}^{-1}$ & 80.50 & 81.02 & 75.11 & 77.51 & 78.54 & 0.8581 & 3.6802 \\
\hline Triglyceride, $\mathrm{mg} \mathrm{dL}^{-1}$ & 44.99 & 50.05 & 47.01 & 50.76 & 48.20 & 0.5702 & 2.0109 \\
\hline Urea, mg dL ${ }^{-1}$ & 41.10 & 40.82 & 45.03 & 41.84 & 42.20 & 0.5601 & 1.5963 \\
\hline Creatinine, $\mathrm{mg} \mathrm{dL}^{-1}$ & 0.775 & 0.748 & 0.760 & 0.691 & 0.743 & 0.1757 & 0.3907 \\
\hline Albumin, $\mathrm{g} \mathrm{dL}^{-1}$ & 5.37 & 5.59 & 5.18 & 5.95 & 5.52 & 0.4606 & 0.2534 \\
\hline Total protein, $\mathrm{g} \mathrm{dL}^{-1}$ & 12.59 & 12.87 & 12.83 & 11.72 & 12.50 & 0.7334 & 0.9233 \\
\hline
\end{tabular}

SEM: Standard error of the mean. 
legumes compared to grasses, increases $\mathrm{K}_{\mathrm{p}}$ of the digesta through the gastrointestinal tract, allowing a greater consumption due to a fast emptying. Characteristics of the total diet from attributes describing mechanistic digesta flow through the rumen like particle size, rate of particle size reduction, and functional specific gravity (Krizsan et al., 2010). In addition, legumes have a lower particle size (Kammes and Allen, 2012), which contributes positively to a higher transit of the digesta by the gastrointestinal tract, leading to an increased consumption. The increase in the transit of the digesta is evidenced in this study both by the higher estimated $\mathrm{K}_{\mathrm{p}}$ and by the smaller footprint of the digesta verified by the lower weight of the gastrointestinal content (Table 3).

It was found that the consumption values for DM of all treatments were above the reference value for animals between 20 and $30 \mathrm{~kg}$ and that there was a gain of $200 \mathrm{~g} \mathrm{~d}^{-1}$ provided by the NRC (2007). This resulted in nutrient increase (Table 2), except for the NDF fraction since nutrients represent fractions of DM.

The increase in the consumption did not reflect in an increase in the total intake time. On the contrary, it decreased with increasing levels of alfalfa (Table 3) resulting in an improved feed efficiency. The decrease in the total intake time of the animals was possibly due to a decrease in the consumption of the NDF fraction (Table 2 ), which decreases its contents in diets with high levels of alfalfa (Table 1). It is known that the fiber fraction represents the main physical parameter in the regulation of feed intake because less fibrous diets occupy less space in the reticulo-rumen, promoting less filling and a shorter intake time. Similarly, the decrease in total chewing time was because of the increase in alfalfa levels. They provided less NDF (Table 1), since they are responsible for a greater rumination stimulation. As a result, there was an increase in the total resting time as a result of less time spent with chewing and ingestion (Table 3). It seems to indicate that the animals had their feeding behavior regulated especially by physiological factors and specifically by the contents of glucose (Table 4), as asserted by the glucostatic theory.

The increased intake of feed with Bermuda grass hay replaced by alfalfa hay promoted a higher content of blood glucose (Table 4). This increase may have been a result of an increased availability of the substrate due to the increase in consumption because glucose is a substrate essential to the activities of various organs such as the brain, medulla, lens, eye cornea and testicles. Ruminants absorb little glucose and have no glucokinase activity in the liver, and nearly all of their glucose needs must be compensated by gluconeogenesis. Propionate is the principal source of carbon for glucose synthesis in liver, which meets $85 \%$ $90 \%$ of the body glucose requirements in sheep (Catunda et al., 2013; Watanabe et al., 2014). Alfalfa hay had a more effective role than sodium propionate on calf performance and rumen development (Beiranvand et al., 2014).
The equality of biochemical blood parameters evidences the nutritional value of alfalfa because, despite a decrease in the digestibility of some nutrients, the animals did not have to mobilize the main form of body energy storage: triacylglycerol, nor were there no changes in cholesterol levels, which maintains a direct relation with triacylglycerols because they are transported together by lipoproteins. Likewise, the comparable levels of blood urea indicate the absence of host protein degradation evidenced by the equivalence in mean total protein. This suggests a rumen origin for blood urea because the determination of total protein is based on the quantification of peptide bonds, thus revealing no deamination, which can be confirmed by the equivalence in average creatinine (Table 4), a metabolite that, according Chizzotti et al. (2008), has a proportional relation with body muscle degradation.

\section{CONCLUSION}

The replacement of Bermuda grass hay by alfalfa hay to promote improvement in the performance is not recommended.

\section{ACKNOWLEDGEMENTS}

The authors wish to thank the Fundação de Amparo à Ciência e Tecnologia do Estado de Pernambuco (FACEPE) for their financial support.

\section{REFERENCES}

Agudelo, J.C.C. 2007. Efecto de la utilización de arbóreas y arbustivas forrajeras sobre la dinámica digestiva en bovinos. Revista Lasallista de Investigación 4:40-50.

AOAC. 1990. Official methods of analysis. Association of Official Analytical Chemists (AOAC), Washington, D.C., USA.

Beiranvand, H., Ghorbani, G.R., Khorvash, M., Nabipour, A., Dehghan-Banadaky, M., Homayouni, A., et al. 2014. Interactions of alfalfa hay and sodium propionate on dairy calf performance and rumen development. Journal of Dairy Science 97:2270-2280.

Berends, H., Van der Borne, J.J.B.C., Stockhofe-Zurwieden, N., Gilbert, M.S., Zandstra, T., Pellikaan, W.F., et al. 2015. Effects of solid feed level and roughage-to-concentrate ratio on ruminal drinking and passage kinetics of milk replacer, concentrates, and roughage in veal calves. Journal of Dairy Science 98:5621-5629.

Bureenok, S., Sisaath, K., Yuangklang, C., Vasupen, K., and Schonewille, J.Th. 2016. Ensiling characteristics of silages of Stylo legume (Stylosanthes guianensis), Guinea grass (Panicum maximum) and their mixture, treated with fermented juice of lactic bacteria, and feed intake and digestibility in goats of rations based on these silages. Small Ruminant Research 134:84-89.

Cannon, S.J., Fahey Jr., G.C., Murphy, M.R., Dikeman, C.L., Miller, B.L., and Drackley, J.K. 2010. Inclusion of psyllium in milk replacer for neonatal calves. 1. Effects on growth, digesta viscosity, rate of passage, nutrient digestibilities, and metabolites in blood. Journal of Dairy Science 93:3652-3660. 
Casali, A.O., Detmann, E., e Valadares Filho, S.C. 2008. Influência do tempo de incubação e do tamanho de partículas sobre os teores de compostos indigestíveis em alimentos e fezes bovinas obtidos por procedimentos in situ. Revista Brasileira de Zootecnia 37:335-342.

Catunda, A.G.V., Lima, I.C.S., Bandeira, G.C., Gadelha, C.R.F., Pereira, E.S., Salmito-Vanderley, C.S.B., et al. 2013. Blood leptin, insulin and glucose concentrations in hair sheep raised in a tropical climate. Small Ruminant Research 114:272-279.

Chizzotti, M.L., Valadares Filho, S.C., Valadares, R.F.D., Chizzotti, F.H.M., and Tedeschi, L.O. 2008. Determination of creatinine excretion and evaluation of spot urine sampling in Holstein cattle. Livestock Science 113:218-225.

Clauss, M., Lechner, I., Barboza, P., Collins, W., Tervoort, T.A., Südekum, K.H., et al. 2011. The effect of size and density on the mean retention time of particles in the reticulorumen of cattle (Bos primigenius f. taurus), muskoxen (Ovibos moschatus) and moose (Alces alces). British Journal of Nutrition 105:634-644.

Gusha, J., Manyuchi, C.R., Imbwayaro-Chikosi, I.V., Hamandishe, V., Katsande, S., and Zvinorova, P.I. 2014. Production and economic performance of F1-crossbreddairy cattle fed nonconventional protein supplements in Zimbabwe. Tropical Animal Health and Production 46:229-234.

Gusha, J., Ngongoni, N.T., and Halimani, T.E. 2013. Nutritional composition and effective degradability of four forage trees grown for protein supplementation. Journal Animal Feed Research 3:170-175.

Kammes, K.L., and Allen, M.S. 2012. Rates of particle size reduction and passage are faster for legume compared with coolseason grass, resulting in lower rumen fill and less effective fiber. Journal of Dairy Science 95:3288-3297.

Krizsan, S.J., Ahvenjärvi, S., and Huhtanen, P. 2010. A metaanalysis of passage rate estimated by rumen evacuation with cattle and evaluation of passage rate prediction models. Journal of Dairy Science 93:5890-5901.

Lima Jr., D.M., Carvalho, F.F.R., Ribeiro, M.N., Batista, A.M.V., Ferreira, B.F., and Monteiro, P.B.S. 2014. Effect of the replacement of Tifton 85 with Maniçoba hay on the performance of Morada Nova hair sheep. Tropical Animal Health and Production, 46:995-1000.

Maciel, M.V., Carvalho, F.F.R., Batista, A.M.V., Guim, A., Souza, E.J.O., Maciel, L.P.A.A., et al. 2015. Carcass and non-carcass characteristics of sheep fed on cassava (Manihot pseudoglaziovii Pax \& K. Hoffm.) Chilean Journal of Agricultural Research 73:307-312.
Manni, K., Rinne, M., and Huhtanen, P. 2013. Comparison of concentrate feeding strategies for growing dairy bulls. Livestock Science 152:21-30.

Martin, P., and Bateson, P. 1988. Measuring behavior: An introductory guide. $3^{\text {rd }}$ ed. 254 p. University Press, Cambridge, New York, USA.

Missio, R.L., Brondani, I.L., Freitas, L.S., Sachet, R.H., Silva, J.H.S., e Restle, J. 2009. Desempenho e avaliação econômica da terminação de tourinhos em confinamento alimentados com diferentes níveis de concentrado na dieta. Revista Brasileira de Zootecnia 38:1309-1316.

NRC. 2001. Nutrient requirements of dairy cattle. $7^{\text {th }}$ ed. National Academy Press, Washington D.C., USA.

NRC. 2007. Nutrient requirements of small ruminants: Sheep, goats, cervids, and New World camelids. 347 p. National Research Council (NRC), National Academy of Science, Washington, D.C., USA.

Riaz, M.Q., Südekum, K.H., Clauss, M., and Jayanegara, A. 2014. Voluntary feed intake and digestibility of four domestic ruminant species as influenced by dietary constituents: A metaanalysis. Livestock Science 162:76-85.

Sniffen, C.J., O'Connor, J.D., Van Soest, P.J., Fox, D.G., and Russell, J.B. 1992. A net carbohydrate and protein system for evaluating cattle diets: II. Carbohydrate and protein availability. Journal of Animal Science 70:3562-3577.

Vieira, E.L., Batista, A.M.V., Guim, A., Carvalho, F.F.R., Nascimento, A.C., Aráujo, R.F.S., et al. 2008. Effects of hay inclusion on intake, in vivo nutrient utilization and ruminal fermentation of goats fed spineless cactus (Opuntia ficus-indica Mill) based diets. Animal Feed Science and Technology 141:199-208.

Watanabe, H., Saito, R., Nakano, T., Takahashi, H., Takahashi, Y., Sumiyoshi, K., et al. 2014. Effect of peripheral 5-HT on glucose and lipid metabolism in wether sheep. PLOS ONE 9:1-12.

Weiss, W.P. 1999. Energy prediction equations for ruminant feeds. p. 176-185. In Cornell Nutrition Conference for Feed Manufacturers, Ithaca. Cornell University, Ithaca, New York, USA. 